\title{
CORRIGENDUM
}

\section{Experimental pig-to-pig transmission dynamics for African swine fever virus, Georgia 2007/1 strain- CORRIGENDUM}

\author{
C. GUINAT, S. GUBBINS, T. VERGNE, J. L. GONZALES, L. DiXON AND \\ D. U. PFEIFFER
}

doi:http://dx.doi.org/10.1017/S0950268815000862, Published online: 20 May 2015.

The authors of the above mentioned article [1] were made aware after publication that the likelihood function defined in the $\mathrm{R}$ script used to implement the maximum likelihood contained an error.

The error has now been rectified in the original $\mathrm{R}$ script. As a result of this correction, the summary should read "Models showed that $\mathrm{R}_{0}$ is $5 \cdot 0$ [95\% confidence intervals (CI): $\left.2 \cdot 4-9 \cdot 1\right]$ within a pen and $2 \cdot 7(95 \%$ CI $0 \cdot 7-5 \cdot 2)$ between pens." Tables 4 and 5 and Figure 2 have been revised and are presented below.

Table 4. Maximum likelihood estimates (95\% confidence intervals) for experimental pig-to-pig transmission parameters for Georgia 2007/1 African swine fever virus strain

\begin{tabular}{llll}
\hline \hline Parameter & Model 1 $(\mathrm{L}=3$ days) & Model 2 $(\mathrm{L}=4$ days $)$ & Model $3(\mathrm{~L}=5$ days $)$ \\
\hline$\beta_{\mathrm{w}}$ (per day) & $0 \cdot 60(0 \cdot 32-0 \cdot 89)$ & $0 \cdot 62(0 \cdot 32-0 \cdot 91)$ & $1 \cdot 17(0 \cdot 58-1 \cdot 75)$ \\
$\beta_{\mathrm{b}}$ (per day) & $0 \cdot 36(0 \cdot 05-0 \cdot 67)$ & $0 \cdot 38(0 \cdot 06-0 \cdot 70)$ & $0 \cdot 61(0 \cdot 16-1 \cdot 06)$ \\
Minimum infectious period duration, $\mathrm{T}=3-6$ days & & & $5 \cdot 03(2 \cdot 38-9 \cdot 12)$ \\
$\mathrm{R}_{0 \mathrm{w}}$ & $2 \cdot 67(1 \cdot 43-4 \cdot 56)$ & $2 \cdot 71(1 \cdot 32-4 \cdot 56)$ & $2 \cdot 73(0 \cdot 70-5 \cdot 19)$ \\
$\mathrm{R}_{0 \mathrm{~b}}$ & $1 \cdot 58(0 \cdot 13-3 \cdot 16)$ & $1 \cdot 66(0 \cdot 28-3 \cdot 31)$ & $80(58-89)$ \\
$\mathrm{HIT}(\%)^{*}$ & $63(30-78)$ & $63(19-78)$ & $9 \cdot 28(2 \cdot 84-18 \cdot 97)$ \\
Maximum infectious period duration, $\mathrm{T}=3-14$ days & & & $4 \cdot 83(1 \cdot 01-11 \cdot 40)$ \\
$\mathrm{R}_{0 \mathrm{w}}$ & $4 \cdot 87(1 \cdot 43-9 \cdot 95)$ & $4 \cdot 99(1 \cdot 36-10 \cdot 13)$ & $89(65-95)$ \\
$\mathrm{R}_{0 \mathrm{~b}}$ & $2 \cdot 80(0 \cdot 32-6 \cdot 51)$ & $3 \cdot 07(0 \cdot 37-6 \cdot 97)$ & $50(26-90)$ \\
$\mathrm{HIT}(\%)^{*}$ & $79(30-90)$ & $73 \cdot 8$ & $50 \cdot 9$ \\
$\mathrm{AIC} \dagger$ & $74 \cdot 3$ & & \\
\hline \hline
\end{tabular}

*Herd immunity threshold, †Akaike information criterion

Table 5. Description of outbreaks simulated in a pig unit for Georgia 2007/1 ASFV strain

\begin{tabular}{|c|c|c|c|}
\hline Parameter & $\begin{array}{l}\text { Model } 1 \\
(\mathrm{~L}=3 \text { days })\end{array}$ & $\begin{array}{l}\text { Model } 2 \\
(\mathrm{~L}=4 \text { days }))\end{array}$ & $\begin{array}{l}\text { Model } 3 \\
(\mathrm{~L}=5 \text { days })\end{array}$ \\
\hline \multicolumn{4}{|l|}{ Infectious period duration, $T=3-6$ days } \\
\hline Probability that outbreak does not occur after introduction of ASFV in the farm & $0 \cdot 18$ & $0 \cdot 17$ & $0 \cdot 09$ \\
\hline $\begin{array}{l}\text { Probability that outbreak does not lead to infection of all population after } \\
\text { introduction of ASFV in the farm }\end{array}$ & $0 \cdot 48$ & $0 \cdot 43$ & $0 \cdot 15$ \\
\hline \multicolumn{4}{|l|}{ Infectious period duration, $T=3-14$ days } \\
\hline Probability that outbreak does not occur after introduction of ASFV in the farm & $0 \cdot 11$ & $0 \cdot 10$ & $0 \cdot 05$ \\
\hline $\begin{array}{l}\text { Probability that outbreak does not lead to infection of all population after } \\
\text { introduction of ASFV in the farm }\end{array}$ & $0 \cdot 21$ & $0 \cdot 19$ & $0 \cdot 09$ \\
\hline
\end{tabular}

This is an Open Access article, distributed under the terms of the Creative Commons Attribution licence (http://creativecommons.org/licenses/by/4.0/), which permits unrestricted re-use, distribution, and reproduction in any medium, provided the original work is properly cited. 

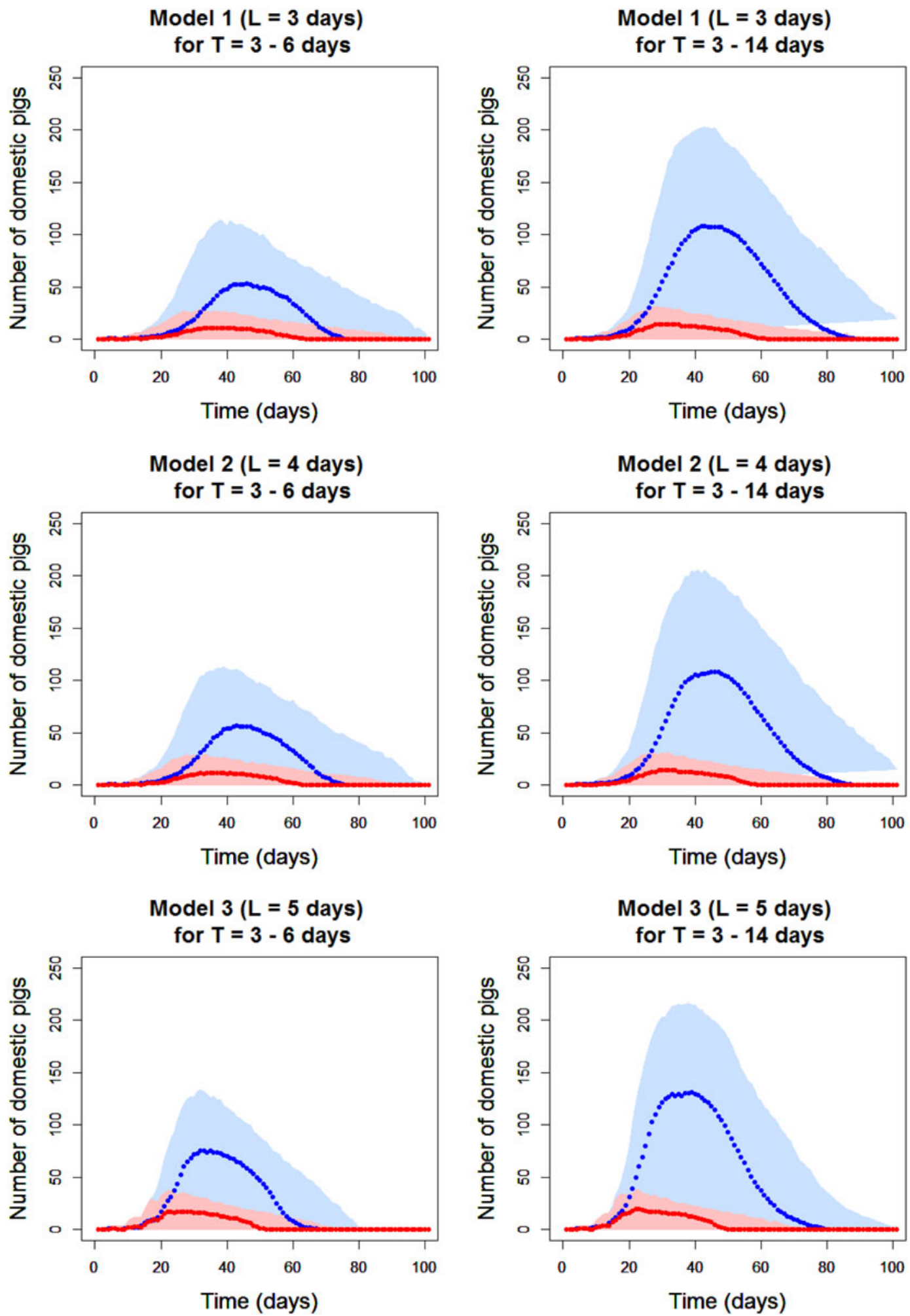

The discussion should read "Model 3, assuming a 5 day-latent period and using presence of live virus in blood as a marker of infectiousness, had the smallest AIC value and was thus the model with the best fit to the data from the transmission experiments." and "Results demonstrate that, assuming a mean infectious period of $4 \cdot 5$ days, infectious pigs would infect on average $5 \cdot 0[95 \%$ confidence intervals (CI): 2.4-9.1] animals within their pen and $2 \cdot 7(95 \%$ CI $0 \cdot 7-5 \cdot 2)$ animals between pens." 
In addition, the authors would like to add information to clarify the methods which should help other researcher in reproducing the results:

First, equation 1 should read:

$p_{t}=1-\exp \left(-\left(\frac{\beta_{w} I_{B, t}}{N_{B, t}}+\frac{\beta_{b} I_{A, t}}{\left(N_{A, t}+N_{B, t}\right)}\right) \Delta t\right)$, with $\Delta t=2$ days.

Second, an additional model assumption that was not clearly phrased in the original manuscript needs to be considered: animals were considered non-infectious on the day just prior to the day they were first tested positive (even though they were not tested on that day).

Finally, the authors provide with this corrigendum the data tables that were used to estimate the transmission parameters (see Tables S1, S2 and S3).

The authors would like to apologise for any inconvenience caused. They are very grateful to Lasse Engbo Christiansen, Josephine Perch Nielsen and Tinna Stokholm Larsen (DTU, Technical University of Denmark) for their careful review of our work and for bringing this error in the implementation of the methods to our attention.

\section{SUPPLEMENTARY MATERIAL}

For supplementary material accompanying this paper visit http://dx.doi.org/10.1017/S0950268816001667.

\section{REFERENCE}

(1) Guinat C, Gubbins S, Vergne T, Gonzales J L, Dixon L, Pfeiffer D U. (2016). Experimental pig-to-pig transmission dynamics for African swine fever virus, Georgia 2007/1 strain. Epidemiology and Infection, 144, pp 25-34. doi:10.1017/ S0950268815000862. 